\title{
50 years of the Czech Pedagogical Society
}

\section{Tomáš Čech}

Masaryk University, Faculty of Education, Department of Social Education

As in 2014 the Czech Pedagogical Society celebrates its $50^{\text {th }}$ anniversary, we would like to look back at its existence and role in the Czech educational science context. Perhaps symbolically, this short retrospect is associated with one of the milestones in the history of the Society, namely the first ever English issue of Pedagogická orientace, an academic journal published by the Czech Pedagogical Society.

When drafting this paper, we used studies of important Czech educational scientists of the second half of the $20^{\text {th }}$ century, such as J. Kotásek, J. Maňák, and V. Krejčí. Some of them belong to the founders of the Czechoslovak Pedagogical Society in 1964, some of them were significantly involved in its activities.

\section{Significant milestones in the history of the Society from its foundation to the Velvet Revolution}

One of the impulses for the foundation of the Czechoslovak Pedagogical Society as a part of the Czechoslovak Academy of Sciences in 1964, according to J. Kotásek (2005, p. 15), was the Report on urgent tasks of our pedagogical science, released by the Ideological Commission of the Central Committee of the Communist Party of Czechoslovakia. Even though the report was an ideologically conforming document, it has an important place in the history of educational science in the Czech and Slovak context, as it reflected on a number of lasting problems and tasks of educational science. One of the positive results of the perceived need to deal with these problems and tasks was the establishment of the Pedagogical Society, which allowed Czech and Slovak teachers and educational scientists, mainly from among the academic staff, to form a scientific community. Even though the Communist party of Czechoslovakia expected the Society to follow principles and ideas of the Communist regime, this was not the case. The Czechoslovak Pedagogical Society was, at least in the first years of its existence, able to maintain a relative autonomy and power to openly discuss issues connected to educational science. An important opportunity for meetings and discussions were three 
national conferences - in Trnava in 1965 (topic: Twenty years of education and educational science in Czechoslovakia), in Olomouc in 1966 (topic: Methodological issues in educational science) and in Prague in 1968 (topic: Results and perspectives of research in Czechoslovak educational science). Horizons of the Czechoslovak Pedagogical Society and Pedagogická orientace (published since 1967) also provided a platform for academic debate.

After its foundation, the Society was led by Prof. L'udovít Bakoš. In the first year of its existence, the Society had 84 members, and in the next four years grew more than four times. As a part of the Czechoslovak Pedagogical Society, the Slovak committee was gradually created. This led to the establishment of the Slovak Pedagogical Society in 1969, and consequently to the establishment of the Czech Pedagogical Society, too. From available documents it is evident that both societies worked on dealing with Czechoslovak educational issues successfully. It can be concluded that the Czech Pedagogical Society became an important scientific society in the field of educational sciences in the second half of the 1960s, which was significantly supported by the events of the Prague Spring in 1968. However, the work was interrupted by the Normalization period that destroyed all efforts to cultivate relatively "free" educational science in Czechoslovakia. The Czech Pedagogical Society was perceived as a highly risky society (because of democratic thinking of its members) and in the early 1970s temporarily ceased to exist (including publishing of Pedagogická orientace) for political reasons. The Society was re-constituted in 1971, but only as a part of propaganda of the totalitarian Communist regime whose "ambassadors" occupied all the leading positions in the Society. This had a major influence on Czech and Slovak educational science for the following two decades until the end of the 1980s.

\section{Presence and status of the Czech Pedagogical Society among scientific societies}

The beginning of the modern era of the Czech Pedagogical Society dates back to the period after the Velvet revolution in November 1989 for which freedom is characteristic, in the educational science context it is the freedom of speech, thoughts, ideas and research. The Society had to comply with the totalitarian regime no longer so it could react to the actual needs of the society and of educational practice. However, according to J. Maňák: 
As in political life, freedom had taken us somewhat by surprise as we were not adequately prepared... After the liberating cessation of pressure, a search for ideological orientation began in educational science and the almost forgotten traditions were picked up on. Opinion differentiation took place and longsuppressed concepts were discussed again. Gradually, pre-war empirical and spiritual pedagogy was formed again, reform movements constituted alternative schools; congresses, conferences and seminars were held. The Czech Pedagogical Society had an important role again. (Maňák, 2005, p. 59)

The beginning of the 1990s brought significant changes, not only ideological but also conceptual ones. Scientific societies were newly supported by the Council of Scientific Societies of the Czech Republic (as a part of Academy of Sciences of the Czech Republic). The role of the Czech Pedagogical Society somewhat changed. Issues of educational science could be discussed at all educational institutions, which partly weakened educators' need to be a member of a scientific society. The establishment of the Czech Educational Research Association in 1992 also played an important role in finding new direction for the Czech Pedagogical Society. This association took the discussion of current methodological issues of education and educational research under its patronage. Therefore the Czech Pedagogical Society started including teachers as well as academics. It began its efforts to create a common ground for discussion on educational theory and educational practice. The most important event in the modern history of the Czech Pedagogical Society was the organization of the Congress of teachers in 2000, which was attended by 650 educators representing a wide spectrum of teachers of all levels and from all regions of the Czech Republic (Veselá \& Švec, 2001).

The current key task of the Czech Pedagogical Society appears to be reestablishing of Pedagogická orientace which ranks among leading educational academic journals in the Czech Republic. The journal is included in several international databases and is currently published six times a year, the sixth issue of each volume published in English.

In the last two decades, expert sections were established within the Society. Their activities focus on stimulating professional debate in selected topics. For instance, social education was the most discussed topic in the 1990s. Currently, the comparative education section (led by E. Walterová) is very active. The Czech Pedagogical Society is even a member of the World Council of Comparative Education Societies. 
Besides the expert sections and academic orientation of the Society, another focus lies in work within regions of the Czech Republic. Eight regional centers currently exist within the Czech pedagogical society - in Prague, Brno, Olomouc, Ostrava, Hradec Králové, Liberec, České Budějovice and Zlín. Committees of the centers offer a variety of interesting lectures, seminars, workshops and support professional (academic) discussion among its members.

The committee of the Czech Pedagogical Society organizes traditional annual conferences on current topics of education and educational science. These conferences are meant for the Society members, but also for general public (since 1960s). The topics discussed were for example Teacher and pupil in current school (Brno 2008), Ethical issues in educational science (Olomouc 2010 ) or The role of education in contemporary society (Prague 2011). For the last annual conference, twentieth in the row, the issue of Conceptions of education in the current curricular discussion was chosen.

\section{References}

Kotásek, J. (2005). Snahy o vytvoření vědecké komunity v české a slovenské pedagogice v letech 1964-1970. In J. Prokop \& M. Rybičková (Eds.), Proměny pedagogiky (pp. 12-30). Praha: Univerzita Karlova, Pedagogická fakulta.

Krejčí, V. (2005). Čtyřicet let Československé (České) pedagogické společnosti a její pobočky v Ostravě. Pedagogická orientace, 15(4), 62-67.

Maňák, J. (2005). Orientace české pedagogiky a Československá (Česká) pedagogická společnost. Pedagogická orientace, 15(4), 56-61.

Veselá, Z., \& Švec, V. (Eds). (2001). Proměny školy, učitele a žáka na přelomu tisíciletí: protokol ze Sjezdu učitelů v Brně 30.-31. srpna 2000. Brno: Konvoj. 